\title{
Potential of Bacillus subtilis lipopeptides in anti-cancer I: induction of apoptosis and paraptosis and inhibition of autophagy in K562 cells
}

Haobin Zhao, Lu Yan, Xiaoguang Xu, Chunmei Jiang, Junling Shi', Yawen Zhang, Li Liu, Shuzhen Lei, Dongyan Shao and Qingsheng Huang

\begin{abstract}
The lipopeptide iturin from Bacillus subtilis has been found to have a potential inhibitory effect on breast cancer, alveolar adenocarcinoma, renal carcinoma, and colon adenocarcinoma. In this study, the potential of B. subtilis lipopeptides (a mixture of iturin homologues, concentration of $42.75 \%$ ) to inhibit chronic myelogenous leukemia was evaluated using K562 myelogenous leukemia cells. The results showed that the lipopeptides could completely inhibit the growth of K562 at $100 \mu \mathrm{M}$, with an IC50 value of $65.76 \mu \mathrm{M}$. The lipopeptides inhibited the profile of K562 via three pathways: (1) induction of paraptosis indicated by the occurrence of cytoplasmic vacuoles, and swelling of the mitochondria and endoplasmic reticulum (ER) without membrane blebbing in the presence of a caspase inhibitor; (2) inhibition of autophagy progress illustrated by the upregulated expression of LCII and P62; and (3) induction of apoptosis by causing ROS burst, and induction of the intrinsic pathway indicated by the upregulated expression of cytochrome $c$ (Cyto-c), bax, and bad, together with downregulated expression of $B C-$-2. The ROS-dependent apoptosis and caspase-independent paraptosis were verified using the ROS inhibitor and caspase inhibitor, respectively. The extrinsic apoptosis pathway was not involved in the lipopeptide's effects on K562. Overall, the B. subtilis lipopeptides (consisting of a majority of iturin) exhibited promising potential in inhibiting chronic myelogenous leukemia in vitro via simultaneously causing paraptosis, apoptosis, and inhibition of autophagy.
\end{abstract}

Keywords: Lipopeptide, Apoptosis, Anticancer, Paraptosis

\section{Introduction}

Chronic myelogenous leukemia (CML), also called chronic myeloid leukemia, is a cancer involving the bone marrow hematopoietic stem cells. It accounts for approximately $15 \%$ of adult leukemia (Shi et al. 2016). The typical properties of this disease are the chromosomal translocation and increased and unregulated growth of predominantly myeloid cells in the bone marrow, as well as the accumulation of these cells in the blood and spleen (Fu et al. 2016). Although stem cell transplantation (SCT)

\footnotetext{
*Correspondence: sjlshi2004@nwpu.edu.cn

Key Laboratory for Space Bioscience and Biotechnology, School of Life Sciences, Northwestern Polytechnical University, 127 Youyi West Road,
} Xi'an 710072, Shaanxi, China is an efficient method to cure CML, it tends to result in complications. Furthermore, it is very difficult to find a suitable donor for the patient (Kujak and Kolesar 2016). Tyrosine-kinase inhibitor (TKI) is another drug to treat CML and improve the long-term survival rate, greatly reduce pain, and improve the quality of life of patients. However, since it became a prominent anti-cancer drug in 2001, it has been found to be successful in only $5 \%$ of cases (Khan and Bixby 2014; Ross and Mgbemena 2014). TKIs can cause some side effects and certain toxicities, and patients may develop drug resistance or relapse due to chromosomal mutations, and these factors have limited its widespread use. Finding other efficient drugs is imperative to improve the cure rate for CML. 
Bacillus subtilis lipopeptides have been found to have anti-tumor effects (Zhao et al. 2017), including inhibitory effects on human breast cancer in vitro and in vivo through the disruption of the Akt pathway (Dey et al. 2015), and the induction of apoptosis of melanoma A 375 cells by specific interaction with the plasma membrane (Janek et al. 2013) and human leukemia K562 cells associated with caspase-3 and poly(ADP-ribose)polymerase (PARP) protein (Wang et al. 2007). These lipopeptides are composed of a peptide ring and fatty acid chain and exhibit anti-bacterial, anti-inflammatory, anti-viral, and anti-tumor functions in vitro (Zhao et al. 2017). Some of them have been used as antiviral (Huang et al. 2006) and antitumor agents (Lee et al. 2012). Surfactin, iturin, and fengycin are the Bacillus lipopeptides that have been extensively reported because they possess antitumor activities. Surfactin can suppress the proliferation of the human colon carcinoma cell line LoVo (Kim et al. 2007), suppress TPA-induced breast cancer cell invasion through the inhibition of MMP-9 expression (Park et al. 2013b), and kill the human breast carcinoma cell line MCF-7 through a ROS/JNK-mediated mitochondrial/ caspase pathway (Cao et al. 2010). Iturin inhibited the proliferation of breast cancer cells MDA-MB-231 (Dey et al. 2015) and MCF-7, alveolar adenocarcinoma A549, renal carcinoma A498, and colon adenocarcinoma HCT15 (Hajare et al. 2013). Fengycin can block non-small cell lung cancer cell 95D and inhibit the growth of xenografted 95D cells in nude mice (Yin et al. 2013).

Currently, only a few studies are available on the ability of $B$. subtilis lipopeptides to inhibit chronic myeloid leukemia (Wang et al. 2007). However, surfactin has been found to have potential in curing blood diseases, such as preventing platelet aggregation and enhancing fibrinolysis with the facilitated diffusion of fibrinolytic agents (Lim et al. 2005). It was thought to have great advantages over other available thrombolytic agents in urgent thrombolytic therapy due to its fewer side effects and potential for long-term use.

In the present study, B. subtilis lipopeptides mainly being composed of iturin groups were used to treat K562 chronic myelogenous leukemia cells, and the intrinsic mechanisms were analyzed and explained at the gene and protein levels.

\section{Materials and methods}

\section{Preparation of lipopeptide extracts}

Bacillus subtilis CCTCCM207209, previously isolated from soil and stored at the China Center for Type Culture Collection (Wuhan, China), was used in this study to produce lipopeptides. B. subtilis lipopeptides were isolated from the supernatant of $48 \mathrm{~h}$-culture in Nutrient Broth Medium with the inoculation amount of $2 \%$ and fermentation conditions of $32{ }^{\circ} \mathrm{C}, 160 \mathrm{rpm}$ for $48 \mathrm{~h}$ (Inès and Dhouha 2015). The supernatant of the culture broth was collected by a 10-min centrifugation at $8000 \mathrm{rpm} /$ min and $4{ }^{\circ} \mathrm{C}$ and filtered through a microporous filter membrane with pore diameter of $0.22 \mu \mathrm{m}$, followed by the adjustment of $\mathrm{pH}$ to 2.0 with $\mathrm{HCl}$. The supernatant was stored overnight at $4{ }^{\circ} \mathrm{C}$, and then the lipopeptide deposit was collected as a crude lipopeptide using centrifugation $\left(8000 \mathrm{rpm} / \mathrm{min}, 4{ }^{\circ} \mathrm{C}, 10 \mathrm{~min}\right.$ ) (Coutte et al. 2015).

For further purification, the lipopeptide deposit was extracted using methanol, centrifuged $(8000 \mathrm{rpm} / \mathrm{min}$, $4{ }^{\circ} \mathrm{C}, 10 \mathrm{~min}$ ), and then evaporated until almost completely dry. Then the lipopeptide was dissolved in deionized water for further purification using a Shimadzu LC-20A high efficiency liquid chromatography (HPLC) (Shimadzu, Japan) system quipped with a C18 column and detector at 280 and $215 \mathrm{~nm}$. The mobile phase was a mixture of acetonitrile and water containing $0.1 \%$ trifluoroacetic acid with a flow velocity of $1.0 \mathrm{~mL} / \mathrm{min}$ and a sample loading volume of $20-40 \mu \mathrm{L}$. The conditions for gradient elution were set as $0-40 \mathrm{~min}, 5-70 \%$ acetonitrile; $40-55 \mathrm{~min}, 70-100 \%$ acetonitrile; and $55-60 \mathrm{~min}$, acetonitrile. Each fraction was separately collected and freeze-dried to obtain a powder that was further tested for its antitumor activity. The obtained powder was dissolved in pure water for the antitumor activity evaluation.

In order to identify the components of the obtained lipopeptide powder, each fraction separated from the powder was obtained using column chromatography and detected the antitumor activity. As results, the active fractions accounted for $42.75 \%$ of the total content of lipopeptides. As is shown in the Additional file 1: Figure: S1a, the peaks between the two red lines were the active fractions of lipopeptides, corresponding to seven different compounds in HPLC analysis. These active fractions were furtherly analyzed using electrospray ionizationhigh resolution mass spectrometry (ESI-MS) and identified as mainly iturin with molecular weight $(\mathrm{m} / \mathrm{z})$ from 1043.5 to $1065.5 \mathrm{Da}$ according to the detected amino acid sequence (Additional file 1: Figure: S1b) and referring to the previously reports (Pathak and Keharia 2014). These fractions were diverse in the number of carbon atoms from 14 to 16 and similar in production. Such differences did not cause significant difference in the inhibition effect upon K562 cells. Therefore, in order to obtain an overview on the potential antitumor activity of $B$. subtilis lipopeptides, all fractions with antitumor activity were mixed together and used in the present study.

\section{Preparation and treatment of cell cultures}

Human leukemia K562 cells was purchased from the cell bank of the Typical Culture Preservation Committee 
of the Chinese Academy of Sciences, and mycoplasma detection tests were performed on the cells to confirm that there was no occurrence of mycoplasma infection in the cells. The cultivation of cells was grown according to a previously reported method (Prayong et al. 2008) with slight modification. Specifically, the cells were grown at $37^{\circ} \mathrm{C}$ and $5 \% \mathrm{CO}_{2}$ in RPMI 1640 (Hyclone) medium that contained $1.5 \mathrm{~g} / \mathrm{L}$ sodium bicarbonate and $4.5 \mathrm{~g} / \mathrm{L}$ glucose supplemented with $10 \%$ fetal bovine serum (FBS).

For treatments, the purified lipopeptides were added to the culture of $\mathrm{K} 562$ cells at different concentrations of $6.25,12.5,25,50,100$, and $200 \mu \mathrm{M}$ (the concentrations were calculated using $1050 \mathrm{Da}$ as the mean molecular weight of the mixed lipopeptide fractions). At different treatment periods from 0 to $60 \mathrm{~h}$, the cell growth was detected to determine the cell proliferation, and other analyses were carried out at the same time.

\section{Cell proliferation analysis}

The cell proliferation was tested using the Cell Counting Kit-8 (CCK-8, Dojindo, Japan) according to the manufacturer's instructions with slight modification (Eike et al. 2015). K562 cells were seeded in 96-well plates at a density of $1 \times 10^{4}$ cells per well with or without lipopeptide addition. At different growth periods, $10 \mu \mathrm{L}$ CCK-8 (Sigma, USA) solution in PBS was added to each well. Plates were incubated for an additional $2 \mathrm{~h}$, and the viability of the cultured cells was determined. After incubating the cells with CCK-8 solution, the light absorbance of the culture medium in each well was measured at $450 \mathrm{~nm}$ using a microplate reader (Bio-Tek, USA) (Prayong et al. 2008).

\section{Visualization of cell morphology}

According to the IC50 (half maximal inhibitory concentration), the cells ready for morphology analysis were treated with $65.76 \mu \mathrm{M}$ lipopeptide for $48 \mathrm{~h}$. The treatment without lipopeptide addition was used as the control. The cells were seeded into 6-well plates at a density of $1 \times 10^{5}$ cells per well. At the end of the treatment, the cells were visualized using a light microscope (Nikon 80i, Japan).

\section{Transmission electron microscopy}

For electron microscopy analysis of cellular microstructure, treated and untreated $\mathrm{K} 562$ cells were fixed in 2.5\% glutaraldehyde for $2 \mathrm{~h}$ at $4{ }^{\circ} \mathrm{C}$, washed with PhosphateBuffered Saline (PBS, pH 7.2) for $10 \mathrm{~min}$ three times, post fixed in $1 \%$ osmium tetroxide in PBS, washed with $\mathrm{dd}_{2} \mathrm{O}$ for 10 min three times, dehydrated with gradient ethanol, rehydrated with epoxypropane, and subsequently embedded in epoxy resin. Ultrathin Sections $(80 \mathrm{~nm})$ were stained with uranyl and lead acetates and examined under a Hitachi H-600 (Hitachi, Japan) electron microscope at $80 \mathrm{kV}$.

\section{Mitochondrial membrane potential assay}

The mitochondrial membrane potential (MMP) assay was carried out using a mitochondrial membrane potential assay kit with JC-1 (Beyotime, China), which undergoes potential-dependent accumulation in the mitochondria. In the assay, K562 cells were seeded into 96-well plates and treated with various concentrations of lipopeptides for $24 \mathrm{~h}$, and then stained with $25 \mu \mathrm{M} \mathrm{JC}-1$ for $30 \mathrm{~min}$ at $37^{\circ} \mathrm{C}$. After that, the cells were observed with a fluorescence microscope at the test wavelength of $540 \mathrm{~nm}$ (Lin et al. 2017).

\section{Detection of the occurrence of apoptosis}

Apoptosis of the cells was detected using flow cytometry (BD FACSCalibur, USA) after staining with the Annexin V-FITC/PI Apoptosis Detection Kit (Beyotime, China). Cells stained only by annexin $\mathrm{V}$ are considered early apoptotic, and cells stained by both annexin V and PI are late apoptotic.

For the measurements, cells from either control or treated cultures were collected and washed twice with PBS (pH 7.2). Cells were resuspended in $195 \mu \mathrm{L}$ of binding buffer, and then incubated with annexin V-FITC and PI for $15 \mathrm{~min}$ in the dark at room temperature. Finally, the analysis was performed with flow cytometry (BD FACSCalibur, USA) (Xu et al. 2017).

\section{Cell cycle assay}

The distribution of the cells in the different phases was also measured using flow cytometry. PI was used to stain the DNA inside the cells. The portion of cells in different periods can be calculated according to the DNA content. After treatment with or without lipopeptides for $48 \mathrm{~h}$, K562 cells were washed with PBS (pH 7.2) and fixed in $70 \%$ ethanol overnight at $4{ }^{\circ} \mathrm{C}$. Then, PI $(10 \mu \mathrm{g} / \mathrm{mL})$ supplemented with RNase A $(50 \mu \mathrm{g} / \mathrm{mL})$ was added to the cells, which were incubated at $37^{\circ} \mathrm{C}$ for $30 \mathrm{~min}$. Analysis was performed with flow cytometry (BD FACSCalibur, USA).

\section{Visualization of apoptotic nuclear morphology}

When apoptosis occurs, chromatin clumps and integrates, resulting in a crescent shape with margination, and the nuclear membrane disrupts. To visualize this, the lipopeptide-treated cells and untreated cells were washed with PBS three times, fixed with $4 \%$ paraformaldehyde for $10 \mathrm{~min}$, and then stained with Hoechst 33342 (Solarbio, China), which was applied at a concentration of $5 \mu \mathrm{g} /$ $\mathrm{mL}$ and then incubated for $10 \mathrm{~min}$ at room temperature. 
The observations were made with a Nikon 80i fluorescence microscope.

\section{TUNEL assay to determine the activity of endogenous nuclease}

Endogenous nuclease is activated when cell apoptosis begins. Therefore, the DNA chain was cut to form 180 to 200 bp DNA fragments. The terminal deoxynucleotide transferase dUTP nick-end labeling (TUNEL) assay involves the specific addition of fluorescently labeled UTP to the $3^{\prime}$-end of the DNA fragments using terminal deoxynucleotidyl transferase. For measurements, the treated cells were washed with PBS twice, fixed in $4 \%$ paraformaldehyde for $20 \mathrm{~min}$, and washed twice with PBS for $5 \mathrm{~min}$ each, at room temperature. The cells were then incubated at $4{ }^{\circ} \mathrm{C}$ for $5 \mathrm{~min}$ in citrate buffer $(0.1 \%$ Triton $\mathrm{X}-100$ in $0.1 \%$ sodium citrate), followed by washing twice with PBS at room temperature for 5 min each time. The TUNEL reagent (Beyotime, China) was prepared by mixing $5 \mu \mathrm{L}$ of enzyme solution with $45 \mu \mathrm{L}$ of labeling solution. Then, $50 \mu \mathrm{L}$ of TUNEL reaction mixture was added per sample containing approximately $10^{6}$ cells. The mixture was incubated in the dark for $1 \mathrm{~h}$ at $37^{\circ} \mathrm{C}$. Then, the TUNEL reagent was removed, and the cells were washed twice with PBS, 5 min each time at room temperature. The washed cells were immediately viewed using a fluorescence microscope (Crowley et al. 2016).

\section{Measurement of reactive oxygen species (ROS)}

The ROS level was measured using the dichlorodihydrofluorescein diacetate (DCFH-DA) assay. K562 cells were plated at a density of $1 \times 10^{5} / \mathrm{mL}$ in 6 -well plates. Then, $4 \mathrm{~h}$ later, lipopeptides were added for a final concentration of $65.76 \mu \mathrm{M}$, and the plates were maintained at $37^{\circ} \mathrm{C}$ for $48 \mathrm{~h}$. After that, the cells were stained with $10 \mu \mathrm{mol} / \mathrm{L}$ DCFH-DA (Beyotime, China) for $20 \mathrm{~min}$ at $37^{\circ} \mathrm{C}$. Then, the intensity of the fluorescence was examined with a multiwavelength multifunctional enzyme spectrometer (Synergy HT) and observed under a fluorescence microscope (Nikon 80i) (Yuan et al. 2014).

The ROS inhibitor $N$-acetyl-L-cysteine (NAC) was also applied to verify the ROS pathway. The cells were treated with NAC ( $2 \mathrm{mmol} / \mathrm{L}$ as a working concentration) for $1.5 \mathrm{~h}$. Then, the cells were treated with the prepared lipopeptides. After the treatment, the ROS level was measured according to the referred method (Zhang et al. 2010).

\section{Western blot analysis}

The cells treated with lipopeptides and the untreated cells were lysed with a homogenizer using RIPA lysis buffer with PMSF. The lysates were incubated on ice for $30 \mathrm{~min}$ with rotation. After $10 \mathrm{~min}$ of centrifugation at $12,000 \mathrm{rpm}$, the supernatants were collected, and the protein concentration was examined. Appropriate supernatants were boiled in loading buffer, separated by SDS-PAGE, and transferred onto a nitrocellulose membrane. Membranes were blocked with $5 \%(\mathrm{w} / \mathrm{v})$ milk in TBST. Enhanced chemiluminescence (ECL) was used for immunodetection, and the procedure was performed as described in the ECL kit protocol (ServiceBio, China). Briefly, blots were incubated overnight at $4{ }^{\circ} \mathrm{C}$ with specific antibody, washed with TBST, and incubated for another $30 \mathrm{~min}$ at room temperature with the peroxidase-conjugated antibodies. Antibodies of Bcl-2, Bax, BAD, cytochrome $c$ (Cyto-c), MEK1/2, JNK, LC3, P62, caspase-3, caspase- 8 , caspase- 9 , caspase- 12 , and $\beta$-actin were used in the assay.

\section{Cleaved caspase- $3 / 9$ activity assay}

Caspase-3 activity was detected using a Caspase-3 Activity Assay Kit (Beyotime, China). Firstly, the cells were lysed in $100 \mu \mathrm{L}$ lysis buffer for $15 \mathrm{~min}$ on ice. The lysates were then centrifuged at $16,000 \times g$ for $15 \mathrm{~min}$ at $4{ }^{\circ} \mathrm{C}$. The supernatant of the cell lysates was mixed with buffer containing acetyl-Asp-Glu-Val-Asp $p$-nitroanilide (Ac-DEVD-pNA) as a substrate peptide and incubated at $37{ }^{\circ} \mathrm{C}$ for $3 \mathrm{~h}$. The release of $p$-nitroanilide (pNA) was quantified by measuring the absorbance at $405 \mathrm{~nm}$ with a microplate reader (Bio-Tek, USA). The concentration of pNA was calculated from the pNA standard curve. One unit is the amount of enzyme that will cleave $1.0 \mathrm{nmol}$ of the colorimetric substrate Ac-DEVD-pNA per hour at $37^{\circ} \mathrm{C}$ under saturated substrate concentrations. The total protein concentration was measured by the Bradford method. The specific caspase- 3 activity was normalized to the total protein and then expressed as a fold increase or decrease of the caspase- 3 activity compared with the control group (Zhao et al. 2015).

To verify whether caspase-related apoptosis occurred, caspase inhibitor Z-VAD-FMK (methyl (3S)-5-fluoro-3-[[(2S)-2-[[(2S)-3-methyl-2-(phenylmethoxycarbonylamino) butanoyl]amino]propanoyl] amino]-4-oxopentanoate, Beyotime, China) was added to the cultured cells at a final concentration of $20 \mu \mathrm{M}$ to inhibit the apoptosis pathway. After treatment, the cells were subjected to viability analysis using the CCK- 8 assay, caspase-3/9 activity analysis, and TEM detection (Lee et al. 2016).

\section{Statistical analysis}

All data were statistically analyzed using GraphPad Primer 6.0 (GraphPad Software Inc., San Diego, CA, USA). Significant difference analysis was performed using Student's $t$ test. The results are presented as the 
mean $\pm \mathrm{SD}$ (standard deviation). The significance level was set at $P<0.05$.

\section{Results}

\section{B. subtilis lipopeptides inhibit the viability of $\mathrm{K} 562$}

The effect of B. subtilis lipopeptides was analyzed using the CCK-8 assay. In this assay, the amount of yellowcolored formazan dye, generated by the activities of dehydrogenases in cells, is directly proportional to the number of living cells. The value of CCK- 8 is related to the activity of dehydrogenases in cells. Dehydrogenases are stable enzymes, present in all cell types, and are rapidly released into the cell culture medium upon plasma membrane damage. The obtained OD value reflects the amount of residue of live cells with an intact plasma membrane, because the cells, instead of the liquid phase of cell culture, were used in the measurement.

As shown in Fig. 1, the B. subtilis lipopeptides caused significant inhibition of $\mathrm{K} 562$ in a concentration dependent manner, as shown by the great decrease in the number of live cells (Fig. 1a, b). The OD value even decreased during the entire cultivation period when $200 \mu \mathrm{M}$ of lipopeptides was used, indicating that the cells were damaged. The IC50 of the treatment for $48 \mathrm{~h}$ was $65.76 \mu \mathrm{M}$. These results indicated that K562 was sensitive to lipopeptides. Treatment with $65.76 \mu \mathrm{M}$ (approximately $50 \mu \mathrm{g} / \mathrm{L}$ ) of lipopeptides for $48 \mathrm{~h}$ was used in the following studies to illustrate the mechanisms that $B$. subtilis lipopeptides use to inhibit K562.

\section{B. subtilis lipopeptides inhibit the cell circle of $\mathrm{K} 562$}

Some cells were completely damaged or inhibited by the lipopeptides, while Fig. 1a shows the activity of the live cell residue. These live cell residues warrant further examination, because it is unknown if they can maintain normal growth or if they will be disturbed in the growth cycle. In order to clarify this, we measured the cell cycles using flow cytometry.

Figure 2 shows the portion of cells in different periods, which was calculated according to the relationship between the DNA content and the intensity of the PI. The cells that were not treated with lipopeptides maintained relatively stable growth during the entire growth period, as indicated by the relatively stable portion of the cells in each period at 24 and $48 \mathrm{~h}$ (Fig. 2a, c). Compared with the untreated cells, the lipopeptide treatment resulted in an increase in the portion of the cells in G2 phase and a decrease in the cells in S phase at both 24 and $48 \mathrm{~h}$. However, the portion of the cells in G1 phase was almost the same in both control and treated groups (Fig. 2b, d). This indicated that the lipopeptides did not disturb the supply of proteins, the increase of organelles (such as mitochondria, ribosomes), or the growth of cell size in G1 phase, but it inhibited the DNA replication in the $S$ phase. The increase in the portion of $\mathrm{G} 2$ cells might be caused by the retardance of the cell from the prepared G2 phase to the $M$ phase for cell division. Therefore, it can be deduced that the lipopeptides inhibited the growth of live K562 cells by blocking the DNA replication and the formation of microtubules and spindles.

There are three avenues to programmed cell death (PCD), and cancer cells can die as a result of any of these processes: apoptosis, paraptosis, and autophagy. As described above, the number of live cells was reduced by lipopeptides, and death might occur at the early stage of the treatment. These three PCD pathways were all examined in the following studies.
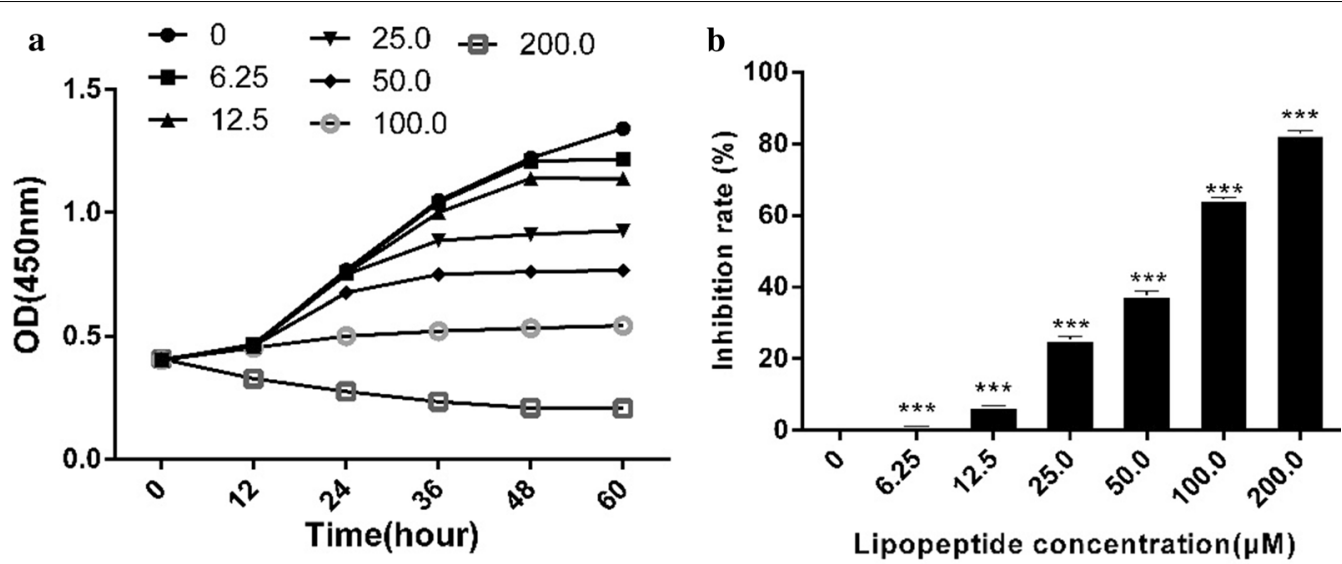

Lipopeptide concentration $(\mu \mathrm{M})$

Fig. 1 Effect of B. subtilis lipopeptides on the viability of K562. a The viability of K562 cells was measured at different periods; the concentration unit was $\mu \mathrm{M}$. $\mathbf{b}$ The inhibition rate was calculated according to the data at $48 \mathrm{~h}$; the significance analysis was performed on the data for treated and control samples using the software GraphPad Prism 6.0. $(P<0.01)$ 

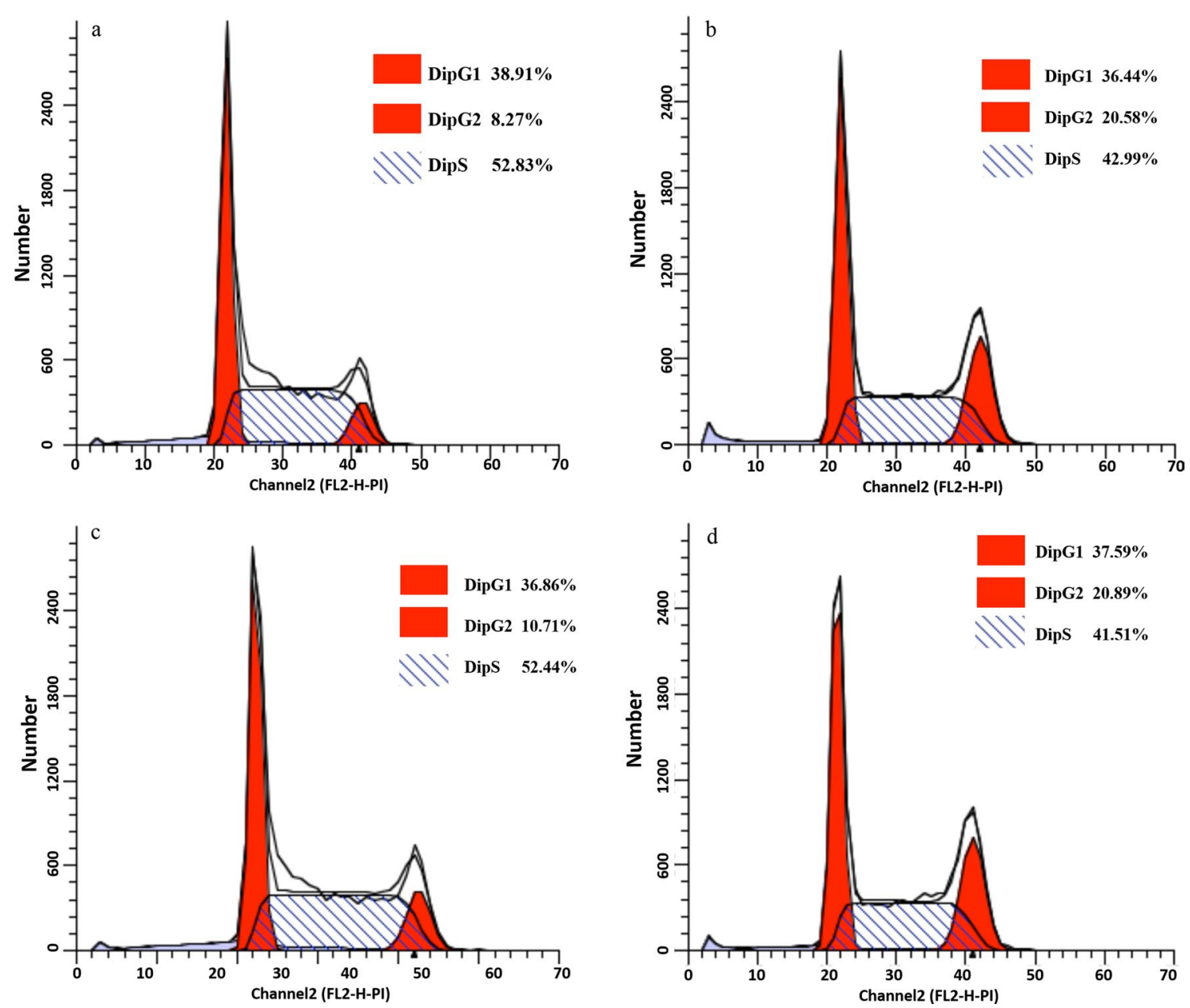

Fig. 2 Flow cytometry analysis on the cell cycle of K562. In the treatment group, cells in S phase decreased significantly and increased in G2/M phase

\section{B. subtilis lipopeptides induce the apoptosis of K562}

Apoptosis is a programmed cell death that is normally regulated by genes and characterized by the occurrence of blebbing, cell shrinkage, release of apoptosis bodies, and the presence of nuclear fragmentation, chromatin condensation, DNA damage, and global mRNA decay. Once it has begun, the process of apoptosis cannot be stopped.

\section{The formation of apoptosis bodies}

As shown in Fig. 3, after treatment for $48 \mathrm{~h}$, an irregular surface, wrinkled edges, shrinkage and cleavage, and many apoptosis bodies were clearly observed in the lipopeptide-treated cells. As to be expected, the number of live cells in the lipopeptide-treated cells was less than that in the untreated cells in a visual field of similar size. All of these observations indicated that lipopeptide triggered the apoptosis of K562 cells. The observation of apoptotic bodies in the TEM photos of the lipopeptide-treated
K562 cells also confirmed the induction of apoptosis (Fig. 9a).

It should be mentioned that the typical phenomena of paraptosis was also observed in a small portion of the cells after the lipopeptide treatment (Fig. 3b), and this was confirmed by the TEM photos (Fig. 9a).

\section{The increase in the percentage of apoptotic cells}

Figure $3 \mathrm{c}, \mathrm{d}$ show the percentage of the cells at different status in the entire culture. The left lower part indicates the percentage of live and normal cells; the left upper part shows the cells in death; the right lower part presents the cells in the early stage of apoptosis; the right upper part shows the cells in the late stage of apoptosis. Compared with the untreated cells, the treatment with lipopeptides for $48 \mathrm{~h}$ caused a significant decrease in the percentage of live cells (from 95.07 to $55.92 \%$ ), significant increase in the percentage of cells at the early apoptosis stage (from 4.00 to $41.59 \%$ ), and a slight increase in the percentage of 

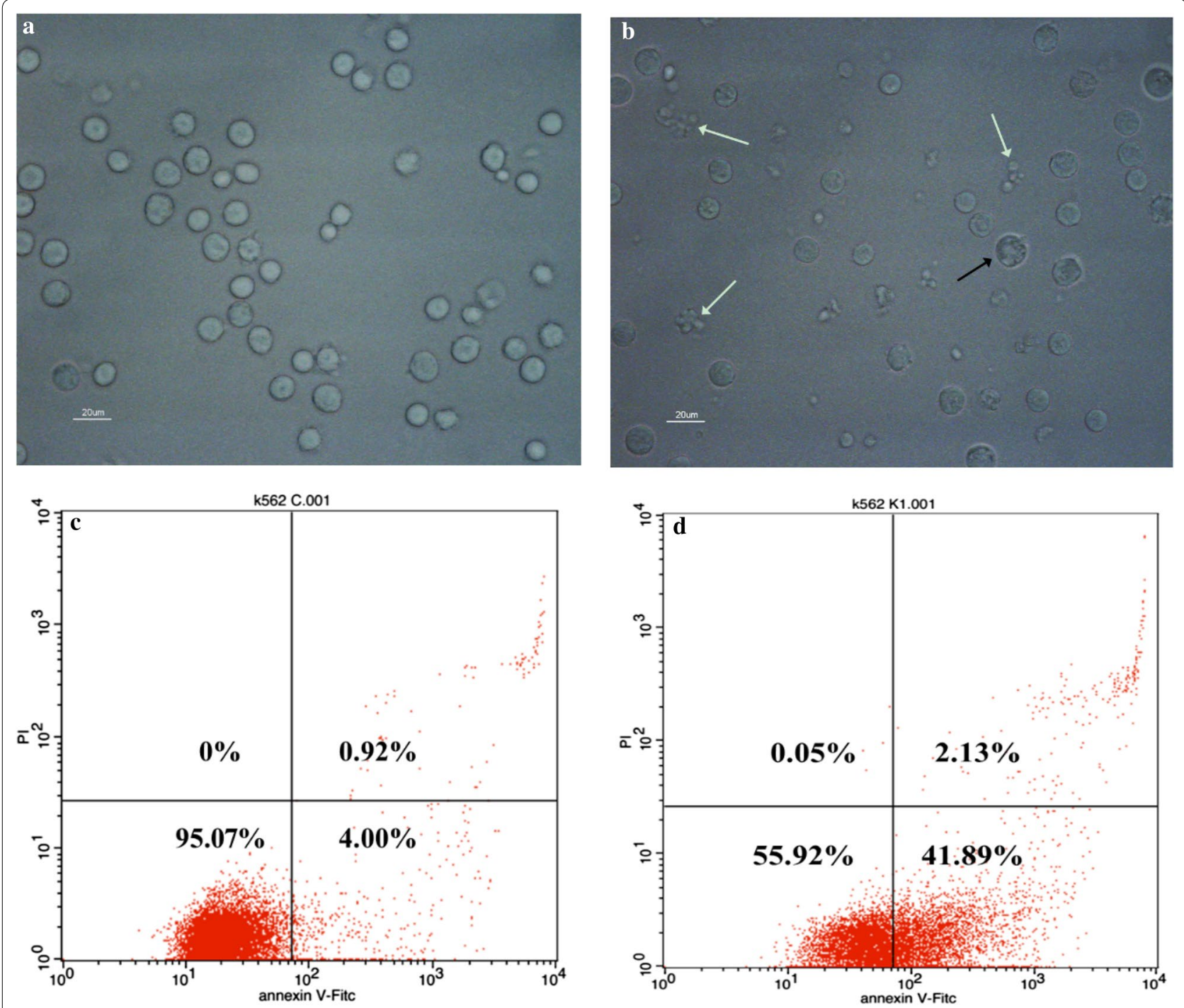

Fig. 3 Micrographs and flow cytometry analysis of K562. The samples were measured after $48 \mathrm{~h}$ without $(\mathbf{a}, \mathbf{c})$ and with $(\mathbf{b}$, d) treatment of $65.76 \mu \mathrm{M}$ lipopeptides. $\mathbf{a}, \mathbf{b}$ The white arrows indicate cells exhibiting the typical phenomena of apoptosis, with membrane blebbing, apoptotic membrane protrusions, and apoptosis bodies. The black arrow indicates the cells exhibiting paraptosis phenomena. The scale bar is $20 \mu \mathrm{m}$. $\mathbf{c}, \mathbf{d}$ The proportion of apoptotic cells increased significantly

cells at the late apoptosis stage (from 0.92 to $2.13 \%$ ). This illustrated that the Bacillus lipopeptides inhibited the viability of K562 by triggering abnormal apoptosis, and especially enhancing the occurrence of apoptosis at the early stage after treatment for $48 \mathrm{~h}$.

\section{The presence of chromatin condensation}

Compared with the control, the treatment with lipopeptides reduced the number of live cells and caused the formation of condensed chromatin and the occurrence of nuclear lysis, which was indicated by the presence of condensed blue points of light inside the treated cells (Fig. 4a, b).

\section{DNA damage}

The TUNEL analysis showed enhanced green fluorescence density in the cells treated with Bacillus lipopeptides, indicating that the DNA in these cells was damaged (Fig. 4c, d). Therefore, it can be concluded that B. subtilis lipopeptides caused DNA damage by triggering the activity of DNase. 

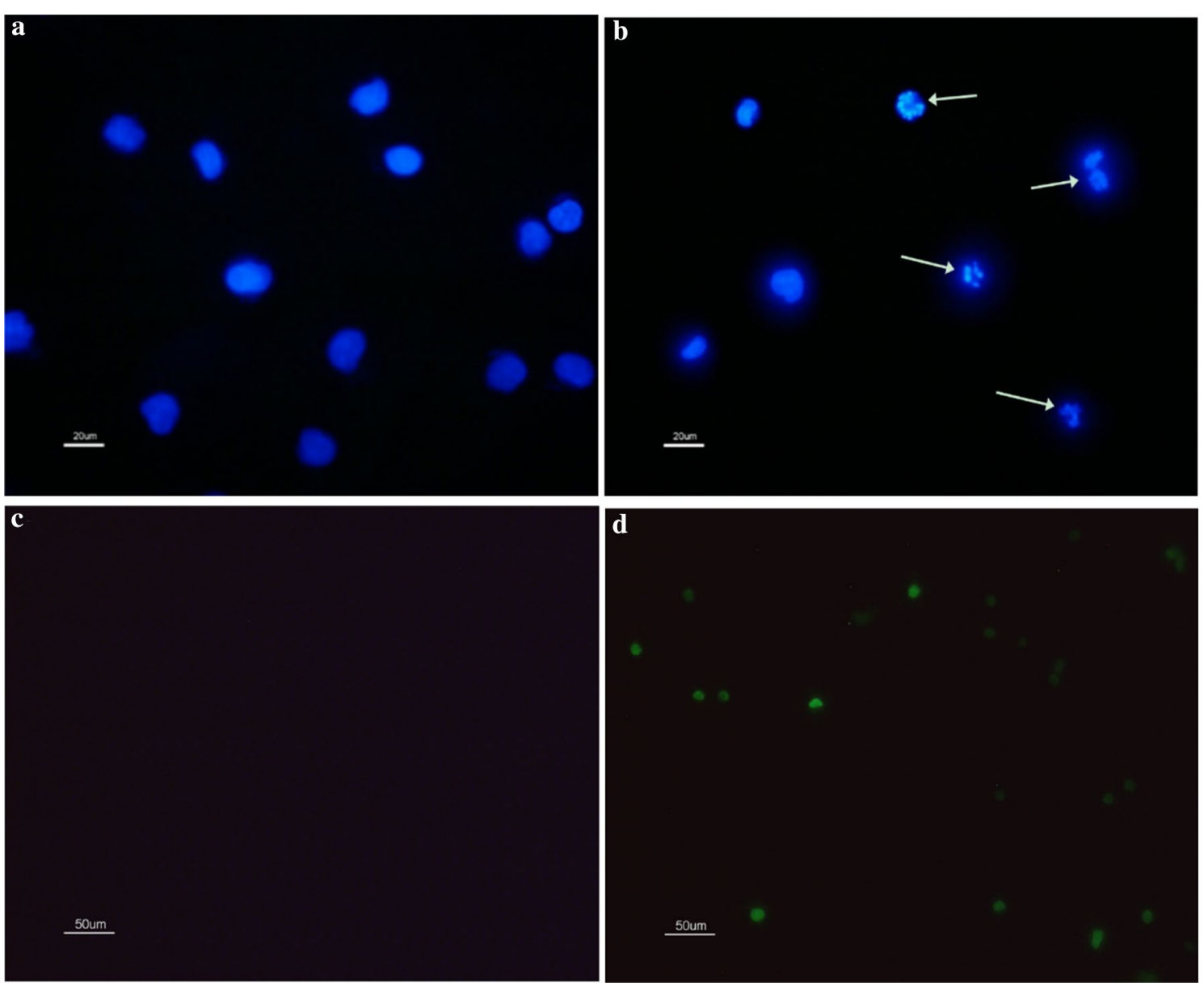

Fig. 4 The nuclear morphology and DNA damage analysis of K562. The samples were measured after $48 \mathrm{~h}$ without $(\mathbf{a}, \mathbf{c})$ and with $(\mathbf{b}$, d) treatment of $65.76 \mu \mathrm{M}$ lipopeptides. $\mathbf{a}, \mathbf{b}$ The white arrows indicate the condensed chromatin; The scale bar is $20 \mu \mathrm{m}$. $\mathbf{c}$, $\mathbf{d}$ The green fluorescence indicates that the cell is apoptotic, and the intracellular DNase is activated to cut off the damaged DNA; The scale bar is $50 \mu \mathrm{m}$

\section{Possible mechanisms for the induction of apoptosis in K562 cells}

Apoptosis is characterized by the caspase-dependent pathways. One is the intrinsic pathway (also called the mitochondria pathway) characterized by the occurrence of mitochondrial swelling, increase in mitochondrial membrane permeability, and the leakage of apoptotic effectors, such as Cyto-c, mitochondrial apoptosisinduced channel (MAC), apoptotic protease activating factor-1 (Apaf-1), pro-caspase-9, caspase-9, caspase-3, $\mathrm{Bcl}-2$, and Bax. Another one is the extrinsic pathway that involves mainly two theories: the TNF-induced (tumor necrosis factor) model and the Fas-Fas ligand-mediated model. The first one is characterized by the increased expression of TNF-alpha receptor (TNFR1); the second one has properties of enhanced expression of death domain (Fas-associated protein with death domain, FADD), caspase-8, and caspase-10. Among these caspases, caspases 8,9 , and 10 are initiator caspases that are activated through binding to specific proteins, while caspase- 3 is an effector caspase that is subsequently activated by the active initiator caspases through proteolytic cleavage. Active caspase- 3 proteolytically degrades the intracellular proteins to carry out the programmed cell death (Chen et al. 2014; Fulda 2011).

Some proteins and factors upstream of the intrinsic and extrinsic pathways also contribute to the occurrence and progress of apoptosis, such as JNK (Tran et al. 2007), extracellular signal-regulated kinases (ERK1/2), tumor protein p53 (Brown et al. 2009), and ROS. Compared with other well-known pathways, the roles of p53 and ROS in apoptosis have only been newly discovered. In the p53 pathway, upon DNA damage or other stresses, various pathways will lead to the dissociation of the p53 and mdm 2 complex. Activated p53 binds DNA and activates expression of several genes including microRNA and inhibits their activity. ROS is normally produced in amounts that correspond to the occurrence of 
mitochondrial damage. It is newly reported that ROS can cause autophagy at low levels and apoptosis at high levels (Wu and Bratton 2013).

Herein, a series of studies was carried out at the level of morphologies and key gene expression to illustrate the mechanism for the apoptosis caused by the lipopeptides. The detailed results are below.

\section{Decrease in mitochondrial membrane potential}

The monomeric JC-1 emitted green fluorescence, indicating a lower mitochondrial membrane potential (MMP). Aggregated JC-1 emitted red fluorescence, which implied a high mitochondrial membrane potential. It can be seen that the control cells mainly showed red fluorescence, while most cells in the Bacillus lipopeptides-treated group showed a significant increase in green fluorescence (Fig. 5). This indicates that the lipopeptides treatment decreased the MMP value of K562 cells to a low level, indicating that it was the lipopeptides that damaged the integrity of the mitochondrial membrane.

\section{Increase in ROS level}

Reactive oxygen species (ROS) are strong oxidizing substances in aerobic organisms and include oxygen radicals and their derivatives. It has been found that ROS is highly related to the occurrence of apoptosis. In the DCFH-DA assay, DCFH-DA can freely penetrate the cell membrane and be hydrolyzed by intracellular esterase to form DCFH after entering the cell. However, DCFH cannot permeate the cell membrane. Intracellular ROS can oxidize DCFH (without fluorescence) to DCF (with fluorescence). Thus, the level of intracellular ROS can be monitored by detecting the fluorescence of DCF. Figure 6 shows that the fluorescence of lipopeptides-treated cells was much stronger than that of the untreated cells.

In order to verify the key roles of ROS in the induction of apoptosis, ROS inhibitor was used together with the lipopeptides. The presence of ROS inhibitor significantly reduced the occurrence of apoptosis and the inhibitory effect of Bacillus lipopeptides on the cell viability of K562 (Fig. 7). The cytoplasmic vacuoles still occurred when the cells were treated with lipopeptides in the presence of ROS inhibitor (Fig. 6d). These indicated that the induction of the enhancement of the ROS level played an important role in the mechanisms for the inhibitory effect of B. subtilis lipopeptides on K562, especially in the apoptosis pathway.

\section{Expression of key proteins in apoptosis signaling pathways}

The following results were obtained according to the analysis shown in Fig. 8a, b and taking into account the currently reported apoptosis pathways. (1) The significantly increased expression of Cyto-c, Bax, Dad, and cleaved caspase- 3 , and the significantly decreased Bcl-2 indicates that the lipopeptides caused the apoptosis of K562 cells through the intrinsic pathway via the mitochondrial pathway. (2) The increased expression of cleaved caspase- 9 and cleaved caspase- 3 represents the activation of initiator caspases and effector caspases, respectively, indicating the detected extrinsic pathway. No significant change in p53, caspase- 8 , and caspase- 12 indicates that the apoptosis caused by the lipopeptides was not related to these factors.

Furthermore, the enzymatic activity analysis showed that the activities of cleaved caspase- 9 and cleaved caspase- 3 were significantly increased by the $B$. subtilis lipopeptide treatment in a time- dependent manner (Fig. 8c,
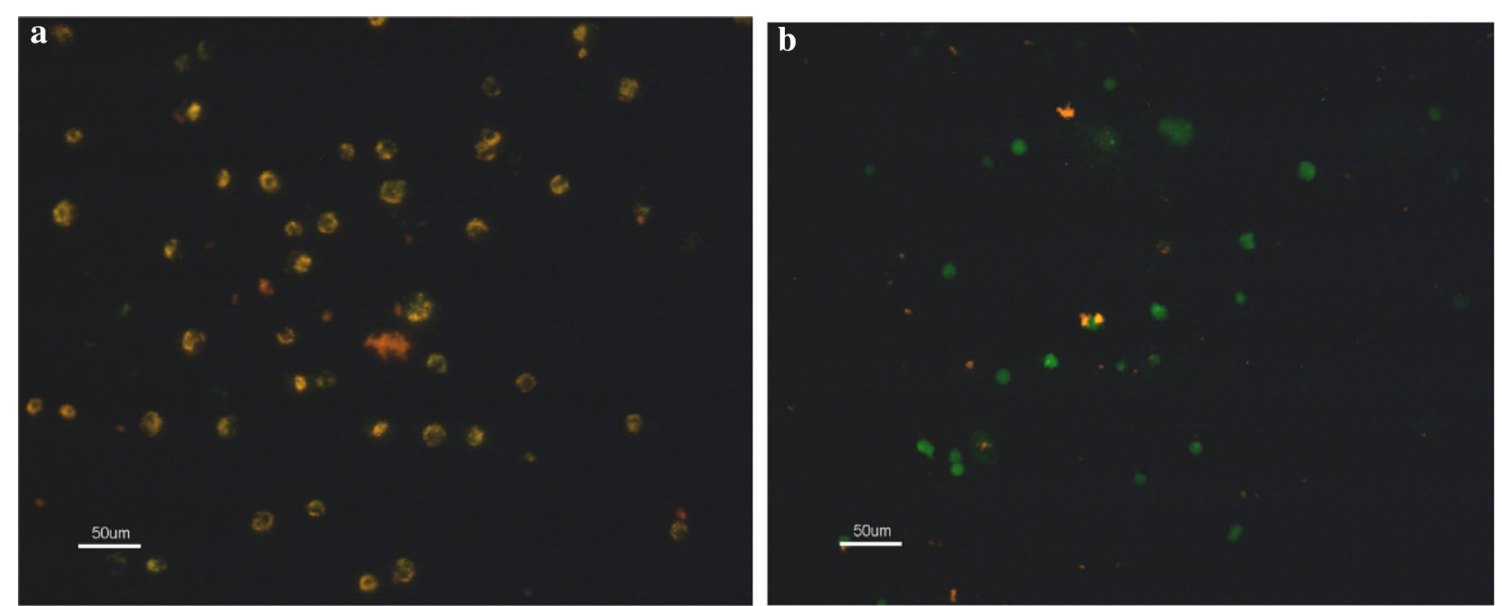

Fig. 5 Mitochondrial membrane potential of (a) untreated and (b) treated K562 cells. Almost all cells in the control group showed more red fluorescence, while the lipopeptide-treated cells displayed green fluorescence. The scale bar is $50 \mu \mathrm{m}$ 

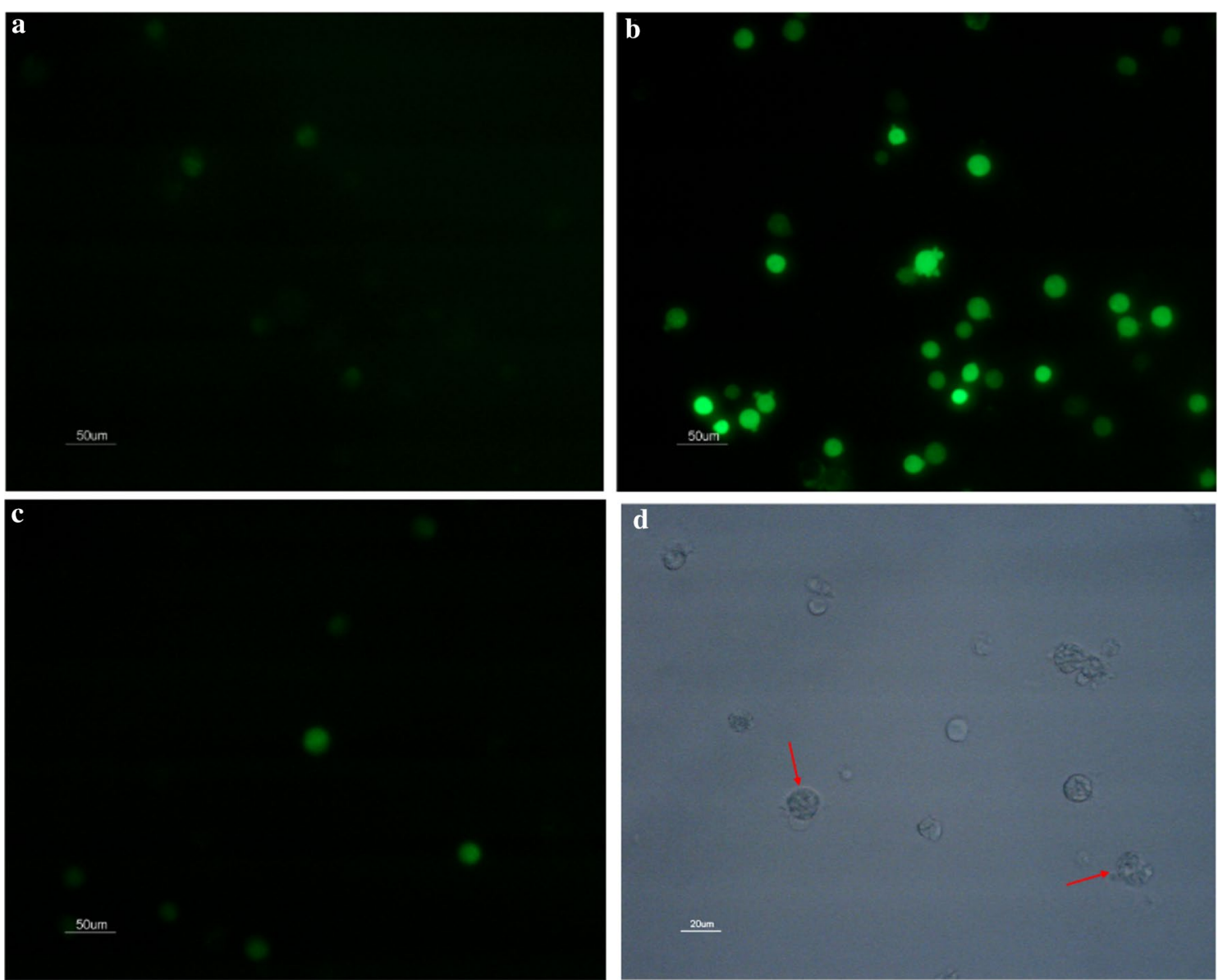

Fig. 6 Reactive oxygen species of K562 cells. a The control cells without lipopeptide treatment; $\mathbf{b}$ the cells treated with $65.76 \mu \mathrm{M}$ lipopeptides for $48 \mathrm{~h}$; c the treated cells with ROS inhibitor; the scale bar is $50 \mu \mathrm{m}$. a The morphology of cells treated with lipopeptides and ROS inhibitors; the scale bar is $20 \mu \mathrm{m}$

d). The presence of caspase inhibitor caused a significant decrease in the inhibitory effect of lipopeptides on the cell viability (Fig. 7) and inhibited the occurrence of apoptosis in K562 cells (Fig. 9).

Overall, it can be concluded that the Bacillus lipopeptides may cause the apoptosis of K562 cells through both the intrinsic pathway and one of the extrinsic pathways.

\section{B. subtilis lipopeptides inhibit the autophagy of $\mathrm{K} 562$}

Cytoplasmic LC3 is commonly used as a marker of autophagosomes because it is the essential part of the vesicle and remains associated until the last moment before its fusion. At the occurrence of autophagy, LC3-I hydrolyzes a small polypeptide and turns itself into (autophagosome) membrane type LC3-II. P62 is another protein associated with autophagy, and it enters mature autophagy and is then degraded (Aburto et al. 2012). The lack of autophagy leads to the accumulation of p62. The increase in the ratio of LC3-II/I and the decrease in p62 are indicators for the development of autophagy. As shown in Fig. 9a, many autophagosomes were found inside the cells treated with the lipopeptides for $48 \mathrm{~h}$. The western blot analysis showed that the treatment with lipopeptides upregulated the expression of LC3II and increased the LC3-II/I ratio, indicating that autophagy was induced. However, the accumulation of p62 was also increased in the lipopeptides-treated cells, indicating the lack of autophagy. This indicates that the autophagy process was inhibited by the lipopeptides and that the autophagy was eventually suppressed. Furthermore, this also indicated that the autophagy progress was inhibited at the stage of the combination of autophagosome with lysosome.

\section{B. subtilis lipopeptides induce the paraptosis of $\mathrm{K} 562$}

Paraptosis is programmed cell death with a lack of apoptotic morphology, characterized by cytoplasmic vacuoles and swelling of the mitochondria and the endoplasmic 


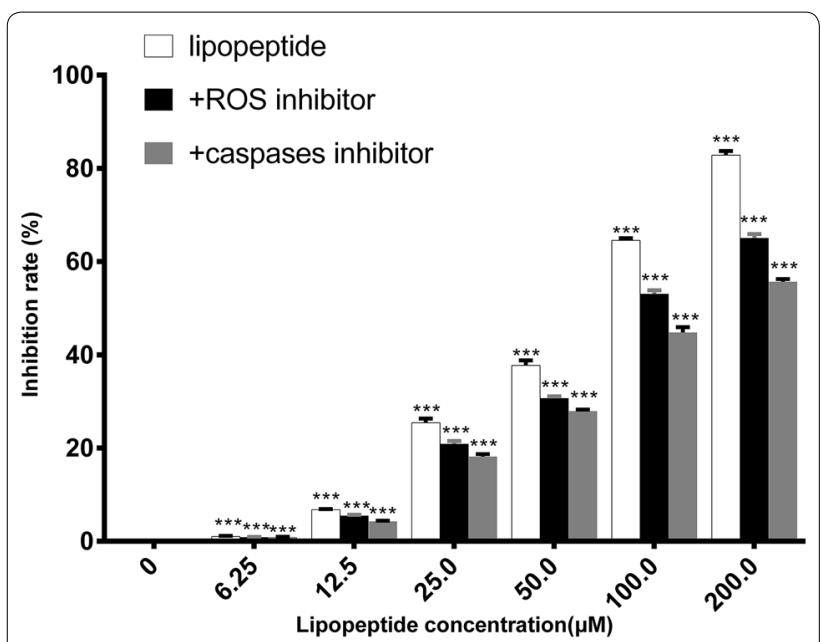

Fig. 7 Influence of ROS inhibitor and caspases inhibitor on the inhibitory effect of lipopeptides on the viability of $\mathrm{K} 562$ cells. The data were obtained after the cells had been treated with lipopeptides for $48 \mathrm{~h}$. When caspase enzyme activity and ROS accumulation were inhibited, the inhibition rate of $\mathrm{K} 562$ cells was significantly reduced

reticulum (ER). This is similar to that of cell necrosis, but necrosis is usually accompanied by cell membrane blebbing. As is shown in Figs. 3 and 6, there are many cytoplasmic vacuoles in the lipopeptide-treated cells. This was more clearly indicated as the occurrence of cytoplasmic vacuoles, swelling of the mitochondria and ER, and the absence of apoptotic bodies and cell membrane blebbing when an apoptosis inhibitor was used together with the lipopeptides (Fig. 9b). This indicated that the formation of cytoplasmic vacuoles was independent of caspases. Moreover, the CCK-8 assay showed that the inhibitory effect of lipopeptides on K562 in the presence of apoptosis inhibitor could still be maintained at more than $50 \%$ of the original level (Fig. 7). This indicated that paraptosis might play an important role in the inhibitory effect of Bacillus lipopeptides on the cell viability of K562.

Overall, the typical markers of paraptosis (the cytoplasmic vacuoles), apoptosis (the apoptotic body), and autophagy (the autophagosome) were all observed in the lipopeptides treated K562 (Fig. 9). The relative pathways were also illustrated in the view of key enzyme activities and the expression levels of key proteins and verified using the corresponding inhibitors. Therefore, it could be concluded that apoptosis, paraptosis, and autophagy occurred during the same period. The overall mechanisms for the effect of Bacillus lipopeptides on the cell viability of K562 was summarized in Fig. 10.

\section{Discussion}

This is the first time to reveal the potential application of and the mechanism for iturin group in inhibiting blood cancer caused by K562. Many reports have indicated that Bacillus lipopeptides engage in anti-fungal, antibacterial, and anti-virus activities, and multiple therapeutic activities, such as anti-inflammation, anti-cancer, neuroprotective effects, inhibition of platelet aggregation, and immunomodulation therapy of diabetes (Zhao et al. 2017). The anti-cancer activities of Bacillus lipopeptides have been demonstrated with human breast cancer MCF-7 cells (Cao et al. 2010), and the human lung cancer cell line 95D (Yin et al. 2013). The current study is the first report describing the effect of Bacillus lipopeptides on blood cancer caused by K562 leukemia cells and indicates that $B$. subtilis lipopeptides, mainly the iturin groups, have potential in treating leukemia.

Further study is still needed to identify the exact structure of the active iturin fractions in this study. Lipopeptides produced by $B$. subtilis are a group of different molecular with similar molecular weight and structure. In this study, only 7 out of more than 30 lipopeptide fractions were found to have inhibitory effect on cancer cell K562. All of these seven fractions showed similar molecular weight and amino acid sequence as iturin. Therefore, it can be concluded that it was the iturin-like fractions in the B. subtilis lipopeptides to possess the anticancer potential, not all lipopeptide fractions. However, further study is still needed to identify the exact structure of these active iturin-like fractions. This work has been on the way in our lab.

Besides of induction of apoptosis in K562 reported by Wang et al. (2007), it was firstly revealed another two ways via by which Bacillus lipopeptides inhibit the viability of $\mathrm{K} 562$ cells: inhibiting autophagy progression and induction of paraptosis. Furthermore, the Bacillus lipopeptides used in this study was with $\mathrm{m} / \mathrm{z}$ from 1043.5 to 1065.5 $\mathrm{Da}$ and identified as iturin groups, being different from that with $\mathrm{m} / \mathrm{z}=1072 \mathrm{Da}$ in previous reports (Wang et al. 2007). In this way, this is the first time to reveal the capability of iturin groups produced by $B$. subtilis to show anticancer potential by inhibiting the viability of $\mathrm{K} 562$ cells.

The anticancer mechanisms of Bacillus lipopeptides have been extensively studied on surfactin, It was found to display an anti-proliferative effect via apoptosis induction, cell cycle arrest, and survival signaling suppression. Surfactin induces apoptosis in MCF-7 human breast cancer cells through a ROS/JNK-mediated mitochondrial/caspase pathway (Cao et al. 2010), suppresses TPAinduced breast cancer cell invasion through the inhibition of MMP-9 expression (Park et al. 2013a), and inhibits the growth of the human lung cancer cell line 95D through 

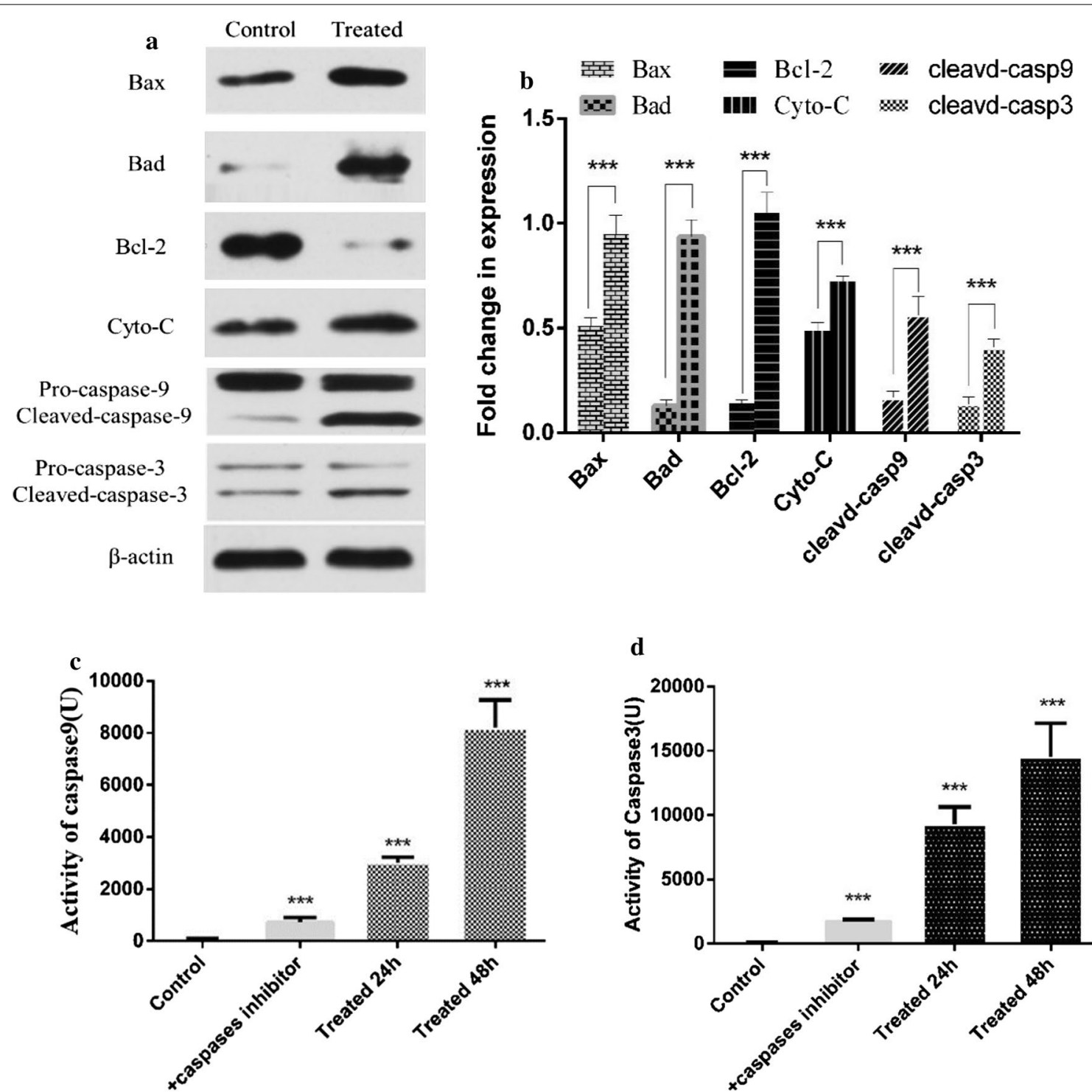

d

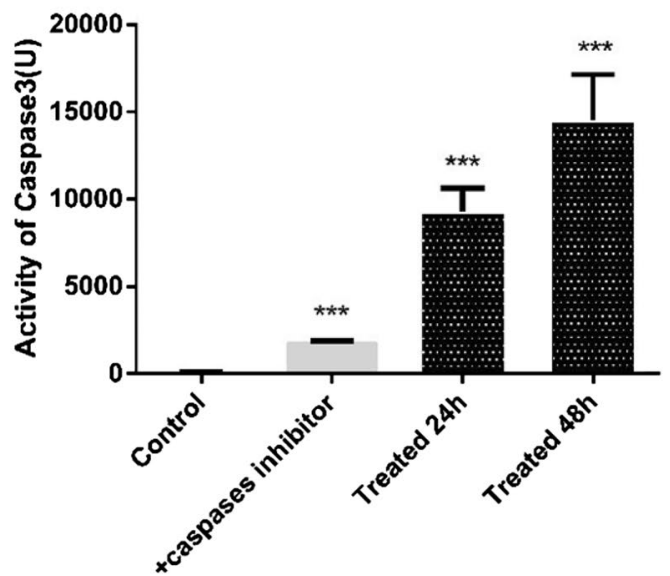

Fig. 8 The expression of apoptosis-related key proteins and the activities of caspase-9 and caspase-3. $\mathbf{a}$, $\mathbf{b}$ Western blot analysis was carried out after $48 \mathrm{~h}$ without (a) and with (b) treatment of $65.76 \mu \mathrm{M}$ lipopeptide. $\mathbf{c}$, d The activity was measured at different period with or without lipopeptide treatment. $\mathbf{c}$ the activity of caspase 9 ; $\mathbf{d}$ the activity of caspase 3 . The caspase enzyme activity of the cells treated with lipopeptide increased as time went by. The caspase inhibitors effectively decreased the caspase enzyme activity

reactive oxygen species production and mitochondriadependent apoptosis (Yin et al. 2013).

The reports of mechanisms for the anticancer effects of iturin and fengycin are comparably much less than those of surfactin. Fengycin interacts with lipid monolayers at the air-aqueous interface-implications on biological membranes. Iturin A inhibits Akt-mediated GSK3beta and FoxO3a signaling and triggers apoptosis in breast cancer (Dey et al. 2015). The induction of apoptosis by a mitochondria-dependent pathway has also been found in the mechanisms for the anti-fungal activities of Bacillus lipopeptides, including surfactin, fengycin, and iturin A. The current study revealed the inhibitory effect of $B$. subtilis lipopeptides consisting of a majority of iturin on K562 blood cancer cells.

Furthermore, the mechanisms for the apoptosis of K562 by B. subtilis lipopeptides were also extensively illustrated in the current study. Apoptosis is a widely reported mechanism for many anticancer agents (Ouyang et al. 2012; Wang et al. 1999). Lipopeptides have been found to kill many types of cancer cells by inhibiting ERK1/2 and Akt activation, causing ROS burst, cell-cycle 

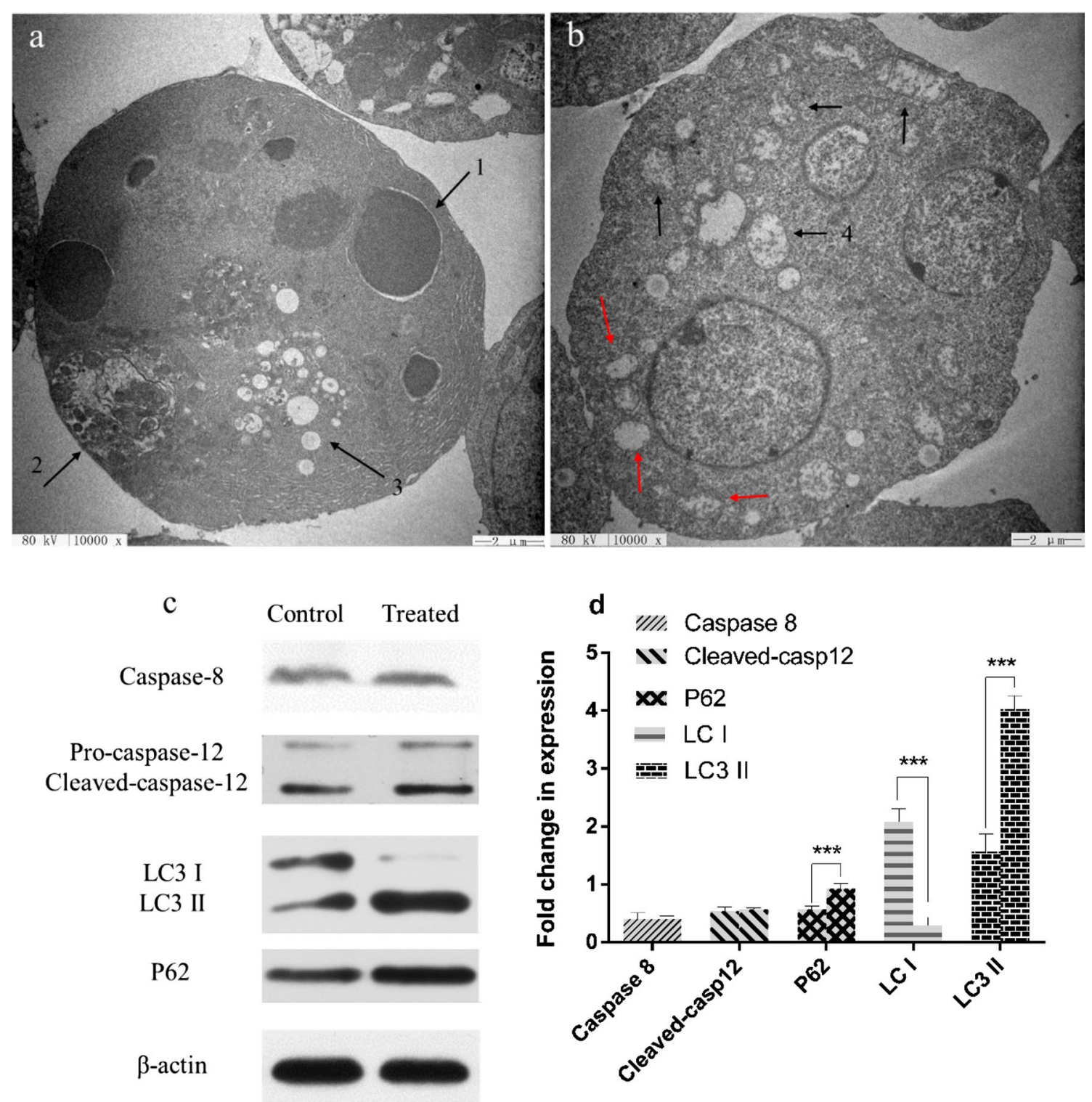

Fig. 9 TEM photo of lipopeptide-treated K562 cells and the western blot analysis of the expression of apoptosis-related proteins. a TEM photo of lipopeptide-treated K562 cells. Arrow 1 shows the apoptotic body; arrow 2 indicates the autophagosome; and arrow 3 indicates the cytoplasmic vacuoles, typical markers of paraptosis. The scale bar is $2 \mu \mathrm{m}$. b TEM photo of $\mathrm{K} 562$ cells treated with lipopeptides together with caspase inhibitors. The black arrows mark the mitochondrion swelling, and the red arrows mark the ER swelling; the scale bar is $2 \mu m$. c The expression of key proteins related to autophagy and paraptosis. $\mathbf{d}$ Quantitative analysis of the levels of gene expression shown in c

arrest, enhancing the bax-to-bcl-2 expression ratio, and caspase activation (Cao et al. 2010; Hajare et al. 2013; Kim et al. 2007; Yin et al. 2013). However, no significant change was found in the expression of the extrinsic apoptosis pathway-related proteins of ERK1/2, Akt, JNK, Fas/ FasL, and p53 (data not shown), indicating that these pathways were not found for the Bacillus lipopeptides tested in this study.
Some research indicates that ROS is involved in regulation of the intrinsic apoptosis pathway and plays important roles in the release of Cyto-c from mitochondria (Ricci et al. 2004; Wu and Bratton 2013). Additionally, ROS indirectly promote the formation of the apoptosome (Korytowski et al. 2011). Furthermore, Cyto-c release also disrupted the electron transport chain (ETC) and stimulated the production of ROS (Borutaite and Brown 2007). ROS were also found to be required for Fas-mediated 


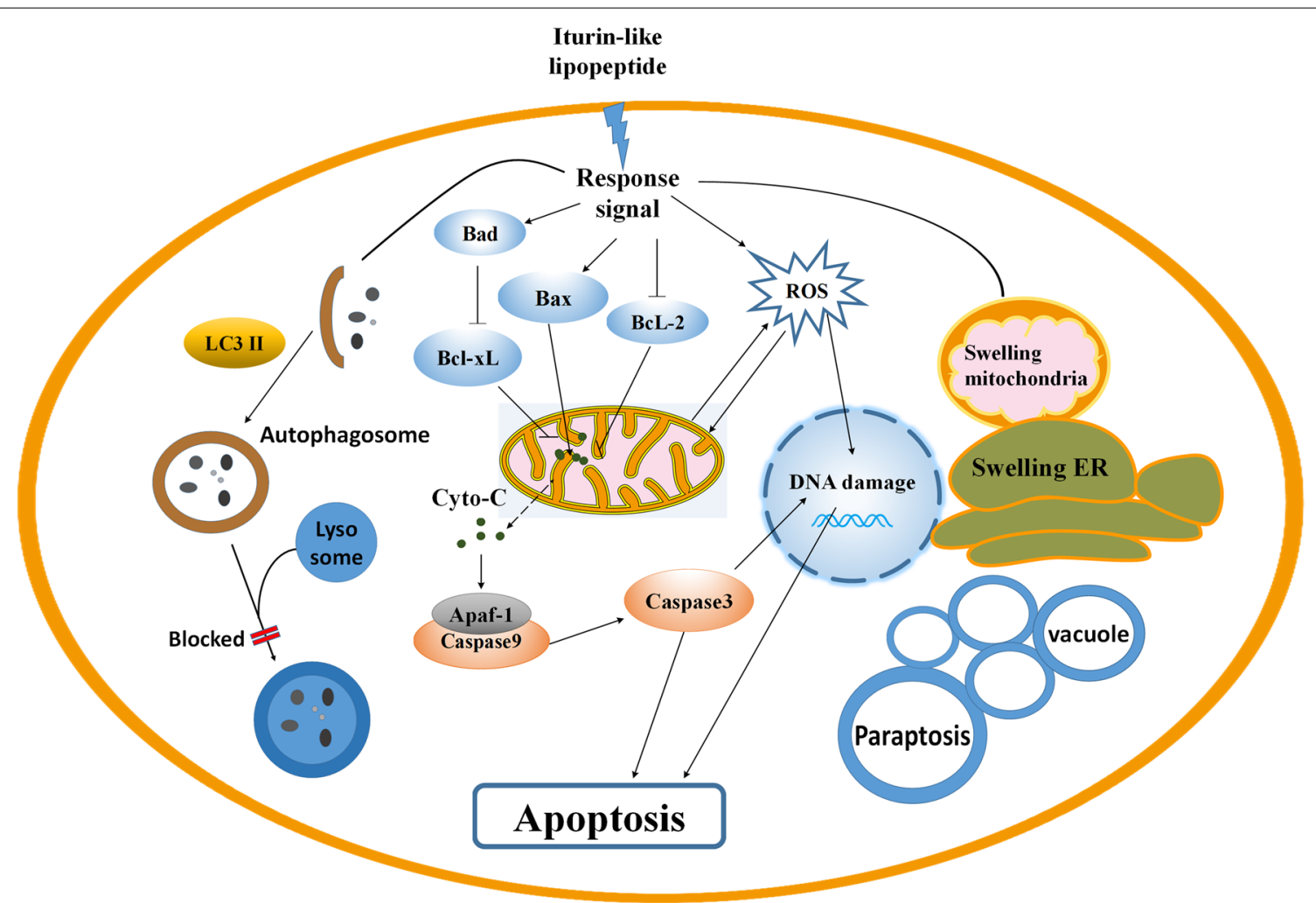

Fig. 10 Overall mechanisms of the inhibitory effect of Bacillus lipopeptides on K562

apoptosome formation (Sato et al. 2004), and promote apoptosis via the extrinsic pathway through upregulation of death receptors or by serving as intermediates in the activation of kinases (Sinha et al. 2013; Tran et al. 2007). In this study, we also identified the important role of ROS in the inhibitory effect of the tested iturin-like B. subtilis lipopeptides on K562. The role of ROS was also identified by the use of ROS inhibitor.

Inhibiting the autophagy progression of $\mathrm{K} 562$ was found as another mechanism for iturin groups to inhibit the viability of $\mathrm{K} 562$ cells. This was verified using an apoptosis inhibitor and measuring the expression of LC3II, p62, and the LC3-II/I ratio, which are important indicators of autophagy (Aburto et al. 2012). Other contributing factors were abnormal mitochondrial function or metabolic disorders caused by cytoplasmic vacuoles.

Furthermore, this study revealed that the iturin groups produced by $B$. subtilis could also induce the occurrence of paraptosis in K562. This is the first time that the capability of B. sutbilis lipopeptides to inhibit cancer cell growth by induction of paraptosis has been illustrated. Paraptosis is a programmed cell death that is different from apoptosis. The typical morphology consists of swelling of the mitochondria and endoplasmic reticulum, which may be attributed to the ion imbalances in the cells that cause excess water to move into the cell. The number and size of vacuoles increases over time. Eventually, the vacuole sizes reach a point of no return, and the cell cannot recover. The dysfunction of the mitochondria and endoplasmic reticulum accompanied with the disorder of metabolism eventually leads to the failure of the cells to survive (Lee et al. 2016), and these phenomena were observed in this study.

In conclusion, we proved that the lipopeptides (the majority consisting of iturin) from $B$. subtilis can completely kill K562 cells at a concentration of $100 \mu \mathrm{M}$, with an IC50 of $65.76 \mu \mathrm{M}$. Additionally, lipopeptides can cause ROS burst in K562 cells, promote the expression of bax and bad and inhibit the expression of Bcl-2, promote the release of Cyto-c, and cause apoptosis. The major effect pathway by which they operate is the endogenous apoptotic pathway. Moreover, the lipopeptides activated the autophagic flow but eventually suppressed it. At the same time, the lipopeptides induced paraptosis, resulting in a large number of cytoplasmic vacuoles, abnormal mitochondrial function, and disorder of cell metabolism. Although the effect of lipopeptides on K562 is obvious, further research is required before it can be used as a drug. Our research provides the initial data that can eventually be used for the treatment for leukemia. 


\section{Additional file}

Additional file 1: Figure $\mathbf{S 1}$. Chromatogram of purification (a) and ESI-MS (b) of major anticancer active lipopeptide fractions. Figure $\mathbf{S 2 .}$ Chromatogram of purification (a) and ESI-MS (b) of major anticancer active lipopeptide fractions.

\begin{abstract}
Abbreviations
CML: chronic myelogenous leukemia; SCT: stem cell transplantation; TKI: tyrosine-kinase inhibitor; HPLC: high efficiency liquid chromatography; CCK-8: Cell Counting Kit-8; IC50: half maximal inhibitory concentration; PBS: phosphate-buffered saline; MMP: mitochondrial membrane potential; PI: propidium iodide; TUNEL: the terminal deoxynucleotide transferase dUTP nick-end labeling; DCFH-DA: 2,7-Dichlorodi-hydrofluorescein diacetate; ROS: reactive oxygen species; RIPA: radio-immunoprecipitation assay; PMSF: phenylmethanesulfonyl fluoride; ECL: enhanced chemiluminescence; TBST: Tris Buffer Solution Tween; BCl-2: B-cell lymphoma-2; Bax: Bcl-2 associated X Protein; Cyto-C: cytochrome c; MEK1/2: mitogen-activated protein kinase 1/2; JNK: c-Jun N-terminal kinase; LC3: microtubule-associated protein 1 light chain 3; Ac-DEVD-pNA: acetyl-Asp-Glu-Val-Asp p-nitroanilide; pNA: $p$-nitroanilide; Z-VAD-FMK: methyl (3S)-5-fluoro-3-[((2S)-2-[[(2S)-3-methyl-2-(phenylmethoxycarbonylamino) butanoyl]amino]propanoyl]amino]-4-oxopentanoate; SD: standard deviation; PCD: programmed cell death; MAC: mitochondrial apoptosis-induced channel; Apaf-1: apoptotic protease activating factor-1; TNFR1:TNF-alpha receptor; FADD: Fas-associated protein with death domain; ERK1/2: extracellular signal-regulated kinases; MMP: mitochondrial membrane potential.
\end{abstract}

\section{Authors' contributions}

$\mathrm{JS}$ and $\mathrm{HZ}$ conceived and supervised the study; JS and $\mathrm{HZ}$ designed experiments and analyzed the data; $H Z, X X, C J, Y Z, L L$, and SL performed the experiments; DS and QH provided help in the experimental design and data analysis; CJ and DS made manuscript revisions. All authors read and approved the final manuscript.

\section{Acknowledgements}

The authors want to thank Qi Li for the help in apoptosis analysis and Key Laboratory for Space Bioscience and Biotechnology, School of Life Sciences, Northwestern Polytechnical University for providing all instruments used in the study.

\section{Competing interests}

The authors declare that they have no competing interests.

\section{Availability of data and materials}

Most of the data supporting our findings are included in the manuscript and the strains used in the study is available by asking the corresponding author.

\section{Consent for publication \\ Not applicable.}

\section{Ethics approval and consent to participate}

This article does not contain any studies with human participants or animals performed by any of the authors.

\section{Funding}

This research was supported by the National Key Technology R\&D Program (2015BAD16B02), the National Natural Science Foundation of China (Grant Nos. 31471718, 1701722), the Modern Agricultural Industry Technology System (CARS-30), and Key research and development plan of Shaanxi Province (2017ZDXL-NY-0304).

\section{Publisher's Note}

Springer Nature remains neutral with regard to jurisdictional claims in published maps and institutional affiliations.
Received: 22 March 2018 Accepted: 28 April 2018

Published online: 09 May 2018

\section{References}

Aburto MR, Hurlé JM, Varela-Nieto I, Magariños M (2012) Autophagy during vertebrate development. Cells 1(3):428. https://doi.org/10.3390/ cells 1030428

Borutaite V, Brown GC (2007) Mitochondrial regulation of caspase activation by cytochrome oxidase and tetramethylphenylenediamine via cytosolic cytochrome c redox state. J Biol Chem 282(43):31124-31130. https://doi. org/10.1074/jbc.M700322200

Brown CJ, Lain S, Verma CS, Fersht AR, Lane DP (2009) Awakening guardian angels: drugging the p53 pathway. Nat Rev Cancer 9(12):862-873. https://doi.org/10.1038/nrc2763

Cao XH, Wang AH, Wang CL, Mao DZ, Lu MF, Cui YQ, Jiao RZ (2010) Surfactin induces apoptosis in human breast cancer MCF-7 cells through a ROS/ JNK-mediated mitochondrial/caspase pathway. Chem Biol Interact 183(3):357-362. https://doi.org/10.1016/j.cbi.2009.11.027

Chen JY, Zhang L, Zhang H, Su L, Qin LP (2014) Triggering of p38 MAPK and JNK signaling is important for oleanolic acid-induced apoptosis via the mitochondrial death pathway in hypertrophic scar fibroblasts. Phytother Res 28(10):1468-1478. https://doi.org/10.1002/ptr.5150

Coutte F, Niehren J, Dhali D, John M, Versari C, Jacques P (2015) Modeling leucine's metabolic pathway and knockout prediction improving the production of surfactin, a biosurfactant from Bacillus subtilis. Biotechnol J 10(8):1216-1234. https://doi.org/10.1002/biot.201400541

Crowley LC, Marfell BJ, Waterhouse NJ (2016) Detection of DNA fragmentation in apoptotic cells by TUNEL. Cold Spring Harb Protoc 10:900-905. https:// doi.org/10.1101/pdb.prot087221

Dey G, Bharti R, Dhanarajan G, Das S, Dey KK, Kumar BN, Sen R, Mandal M (2015) Marine lipopeptide iturin A inhibits Akt mediated GSK3beta and FoxO3a signaling and triggers apoptosis in breast cancer. Sci Rep 5:10316. https://doi.org/10.1038/srep10316

Eike LM, Yang N, Rekdal O, Sveinbjornsson B (2015) The oncolytic peptide LTX-315 induces cell death and DAMP release by mitochondria distortion in human melanoma cells. Oncotarget 6(33):34910-34923. https://doi. org/10.18632/oncotarget.5308

Fu GN, Fan HY, Han XJ, Xin CL (2016) Complex chromosomal rearrangements involving five chromosomes in chronic myelogenous leukemia: a case report. Oncol Lett 11(4):2651-2653. https://doi.org/10.3892/ol.2016.4275

Fulda S (2011) Targeting apoptosis signaling pathways for anticancer therapy. Front Oncol 1:23. https://doi.org/10.3389/fonc.2011.00023

Hajare SN, Subramanian M, Gautam S, Sharma A (2013) Induction of apoptosis in human cancer cells by a Bacillus lipopeptide bacillomycin D. Biochimie 95(9):1722-1731. https://doi.org/10.1016/j.biochi.2013.05.015

Huang X, Lu Z, Zhao H, Bie X, Lü FX, Yang S (2006) Antiviral activity of antimicrobial lipopeptide from Bacillus subtilis fmbj against pseudorabies virus, porcine parvovirus, newcastle disease virus and infectious bursal disease virus in vitro. Int J Pept Res Ther 12(4):373-377. https://doi.org/10.1007/ s10989-006-9041-4

Inès M, Dhouha G (2015) Lipopeptide surfactants: production, recovery and pore forming capacity. Peptides 71:100-112. https://doi.org/10.1016/j. peptides.2015.07.006

Janek T, Krasowska A, Radwanska A, Lukaszewicz M (2013) Lipopeptide biosurfactant pseudofactin II induced apoptosis of Melanoma A 375 cells by specific interaction with the plasma membrane. PLoS ONE 8(3):9. https:// doi.org/10.1371/journal.pone.0057991

Khan AM, Bixby DL (2014) BCR-ABL inhibitors: updates in the management of patients with chronic-phase chronic myeloid leukemia. Hematology 19(5):249-258. https://doi.org/10.1179/1607845413y.0000000119

Kim SY, Kim JY, Kim SH, Bae HJ, Yi H, Yoon SH, Koo BS, Kwon M, Cho JY, Lee CE, Hong S (2007) Surfactin from Bacillus subtilis displays anti-proliferative effect via apoptosis induction, cell cycle arrest and survival signaling suppression. FEBS Lett 581(5):865-871. https://doi.org/10.1016/j. febslet.2007.01.059

Korytowski W, Basova LV, Pilat A, Kernstock RM, Girotti AW (2011) Permeabilization of the mitochondrial outer membrane by Bax/Truncated Bid (tBid) Proteins as sensitized by cardiolipin hydroperoxide translocation 
mechanistic implications for the intrinsic pathway of oxidative apoptois. J Biol Chem 286(30):26334-26343. https://doi.org/10.1074/jbc. M110.188516

Kujak C, Kolesar JM (2016) Treatment of chronic myelogenous leukemia. Am J Health Syst Pharm 73(3):113-120. https://doi.org/10.2146/ajhp140686

Lee JH, Nam SH, Seo WT, Yun HD, Hong SY, Kim MK, Cho KM (2012) The production of surfactin during the fermentation of cheonggukjang by potential probiotic Bacillus subtilis CSY191 and the resultant growth suppression of MCF-7 human breast cancer cells. Food Chem 131(4):13471354. https://doi.org/10.1016/j.foodchem.2011.09.133

Lee D, Kim IY, Saha S, Choi KS (2016) Paraptosis in the anti-cancer arsenal of natural products. Pharmacol Ther 162:120-133. https://doi.org/10.1016/j. pharmthera.2016.01.003

Lim JH, Park BK, Kim MS, Hwang MH, Rhee MH, Park SC, Yun HI (2005) The antithrombotic activity of surfactins. J Vet Sci 6(4):353-355

Lin PY, Tsai CT, Chuang WL, Chao YH, Pan IH, Chen YK, Lin CC, Wang BY (2017) Chlorella sorokiniana induces mitochondrial-mediated apoptosis in human non-small cell lung cancer cells and inhibits xenograft tumor growth in vivo. BMC Complement Altern Med 17(1):88. https://doi. org/10.1186/s12906-017-1611-9

Ouyang L, Shi Z, Zhao S, Wang FT, Zhou TT, Liu B, Bao JK (2012) Programmed cell death pathways in cancer: a review of apoptosis, autophagy and programmed necrosis. Cell Prolif 45(6):487-498. https://doi. org/10.1111/j.1365-2184.2012.00845.x

Park SY, Kim JH, Lee SJ, Kim Y (2013a) Surfactin exhibits neuroprotective effects by inhibiting amyloid beta-mediated microglial activation. Neurotoxicology 38:115-123. https://doi.org/10.1016/..neuro.2013.07.004

Park SY, Kim JH, Lee YJ, Lee SJ, Kim Y (2013b) Surfactin suppresses TPA-induced breast cancer cell invasion through the inhibition of MMP-9 expression. Int J Oncol 42(1):287-296. https://doi.org/10.3892/ijo.2012.1695

Pathak KV, Keharia H (2014) Identification of surfactins and iturins produced by potent fungal antagonist, Bacillus subtilis K1 isolated from aerial roots of banyan (Ficus benghalensis) tree using mass spectrometry. 3 Biotech 4(3):283-295. https://doi.org/10.1007/s13205-013-0151-3

Prayong P, Barusrux S, Weerapreeyakul N (2008) Cytotoxic activity screening of some indigenous Thai plants. Fitoterapia 79(7-8):598-601. https://doi. org/10.1016/j.fitote.2008.06.007

Ricci JE, Munoz-Pinedo C, Fitzgerald P, Bailly-Maitre B, Perkins GA, Yadava N, Scheffler IE, Ellisman MH, Green DR (2004) Disruption of mitochondrial function during apoptosis is mediated by caspase cleavage of the p75 subunit of complex I of the electron transport chain. Cell 117(6):773-786. https://doi.org/10.1016/j.cell.2004.05.008

Ross TS, Mgbemena VE (2014) Re-evaluating the role of BCR/ABL in chronic myelogenous leukemia. Mol Cell Oncol 1(3):e963450. https://doi.org/10.4 $161 / 23723548.2014 .963450$

Sato T, Machida T, Takahashi S, Iyama S, Sato Y, Kuribayashi K, Takada K, Oku T, Kawano Y, Okamoto T, Takimoto R, Matsunaga T, Takayama T, Takahashi M,
Kato J, Niitsu Y (2004) Fas-mediated apoptosome formation is dependent on reactive oxygen species derived from mitochondrial permeability transition in Jurkat cells. J Immunol 173(1):285-296. https://doi. org/10.4049/jimmunol.173.1.285

Shi D, Liu Y, Xi RG, Zou W, Wu L, Zhang ZR, Liu ZY, Qu C, Xu BL, Wang XB (2016) Caveolin-1 contributes to realgar nanoparticle therapy in human chronic myelogenous leukemia K562 cells. Int J Nanomed 11:5823-5835. https:// doi.org/10.2147/ijn.s115158

Sinha K, Das J, Pal PB, Sil PC (2013) Oxidative stress: the mitochondria-dependent and mitochondria-independent pathways of apoptosis. Arch Toxicol 87(7):1157-1180. https://doi.org/10.1007/s00204-013-1034-4

Tran TH, Andreka P, Rodrigues CO, Webster KA, Bishopric NH (2007) Jun kinase delays caspase-9 activation by interaction with the apoptosome. J Biol Chem 282(28):20340-20350. https://doi.org/10.1074/jbc.M702210200

Wang E, Marcotte R, Petroulakis E (1999) Signaling pathway for apoptosis: a racetrack for life or death. J Cell Biochem 75(S32):95. https://doi. org/10.1002/(sici)1097-4644(1999)75:32+3.0.co;2-f

Wang CL, Ng TB, Yuan F, Liu ZK, Liu F (2007) Induction of apoptosis in human leukemia K562 cells by cyclic lipopeptide from Bacillus subtilis natto T-2. Peptides 28(7):1344-1350. https://doi.org/10.1016/j.peptides.2007.06.014

Wu CC, Bratton SB (2013) Regulation of the intrinsic apoptosis pathway by reactive oxygen species. Antioxid Redox Sign 19(6):546-558. https://doi. org/10.1089/ars.2012.4905

Xu WJ, Pan Y, Wang H, Li HY, Peng Q, Wei DC, Chen C, Zheng JH (2017) Synthesis and evaluation of new pyrazoline derivatives as potential anticancer agents in HepG-2 Cell Line. Molecules 22(3):14. https://doi.org/10.3390/ molecules22030467

Yin HP, Guo CL, Wang Y, Liu D, Lv YB, Lv FX, Lu ZX (2013) Fengycin inhibits the growth of the human lung cancer cell line 95D through reactive oxygen species production and mitochondria-dependent apoptosis. Anti-cancer Drug 24(6):587-598. https://doi.org/10.1097/CAD.0b013e3283611395

Yuan D, Wan JZ, Deng LL, Zhang CC, Dun YY, Dai YW, Zhou ZY, Liu CQ, Wang T (2014) Chikusetsu saponin $V$ attenuates MPP +-induced neurotoxicity in SH-SY5Y cells via regulation of Sirt1/Mn-SOD and GRP78/Caspase-12 pathways. Int J Mol Sci 15(8):13209-13222. https://doi.org/10.3390/ ijms150813209

Zhang LA, Lei WW, Wang XD, Tang YN, Song JG (2010) Glucocorticoid induces mesenchymal-to-epithelial transition and inhibits TGF-beta 1-induced epithelial-to-mesenchymal transition and cell migration. FEBS Lett 584(22):4646-4654. https://doi.org/10.1016/j.febslet.2010.10.038

Zhao X, Wang KJ, Hu F, Qian C, Guan HQ, Feng KG, Zhou Y, Chen ZJ (2015) MicroRNA-101 protects cardiac fibroblasts from hypoxia-induced apoptosis via inhibition of the TGF-beta signaling pathway. Int J Biochem Cell Biol 65:155-164. https://doi.org/10.1016/j.biocel.2015.06.005

Zhao HB, Shao DY, Jiang CM, Shi JL, Li Q, Huang QS, Rajoka MSR, Yang H, Jin ML (2017) Biological activity of lipopeptides from Bacillus. Appl Microbiol Biotechnol 101(15):5951-5960. https://doi.org/10.1007/s00253-017-8396-0

\section{Submit your manuscript to a SpringerOpen ${ }^{\odot}$ journal and benefit from:}

- Convenient online submission

- Rigorous peer review

- Open access: articles freely available online

- High visibility within the field

- Retaining the copyright to your article

Submit your next manuscript at $\boldsymbol{\nabla}$ springeropen.com 